\title{
VIEWPOINTS
}

\section{Islamic Responses to the Financial and Economic Crises}

\author{
Abdul Karim Abdullah*
}

An economic crisis is the flip side of a financial crisis. A financial crisis, whether on a personal, national or international level, takes place when economic activity - the source of income - slows down or stops.

Economic activity generates income. When production slows down income paid for the use of the factors of production also falls. As the gross domestic product declines so does national income. When there is a recession or a depression the economy needs to be revived - fast.

An increase in efficiency or productivity contributes to higher profits, higher incomes, and a higher standard of living. Low productivity keeps income at low levels. When income increases without a proportionate increase in productivity, however, it is as if a car engine were running at a higher speed - but in the neutral gear. More income is being generated, but there is little corresponding increase in real wealth.

Islam, in turn, appears to offer effective responses to a variety of crises - including financial and economic ones. Some of those responses take the form of 'commands', and some the form of 'prohibitions'. The responses include fiscal and monetary prudence, social justice (Qur'ān 4:135; 5:8; 6:152; 55:9), higher spending, enforcing fair trade, fulfilling contractual obligations (Qur'ān 5:1), being optimistic, curbing excessive speculation, and providing incentives for genuine wealth creation.

Islam counsels fiscal prudence, which is required on an ongoing basis. Governments must have the will to run surplus budgets during good times, and deficit budgets during difficult times. We save for the rainy day, and spend on the rainy day. The prophet Yusuf accumulated a surplus during the seven good years. The surplus was then used up during the seven lean years (Qur'ān 12:47-8). He applied what we today call 'counter-cyclical fiscal policy'.

The Qur'an frequently exhorts us to spend out of what God has bestowed on us (Qur'ān 2:177; 2:254; 13:22; 57:7). The best way to overcome a recession or depression is to 'spend our way out of it'. Spending will 'prosper thy neighbour'.

* Abdul Karim Abdullah (Leslie Terebessy) is Assistant Research Fellow at IAIS Malaysia. 
Niggardliness will beggar him. We must remember that one person's expense is another person's income.

Money should circulate not only among the rich, but also among all social classes. A well-known verse in the Qur'ān (59:7) confirms this. This should help narrow the gap between the well to do and the impoverished.

Hoarding, exploitation, profiteering, usury, fraud, price fixing, monopolising markets and gambling are prohibited. Trade enriches and creates prosperity (falāh). Usury impoverishes and creates misery. Usury is the reverse of charity. In charity we give; with usury, we take.

Muslims are literally called to 'success' and 'prosperity' (faläh) five times a day during the calls to prayer. Not to be overlooked is the fact that the messenger of God, Muhammad (pbuh) himself was a successful businessman. He exemplified many sound business practices in his own lifetime. He was well known for his honesty and trustworthiness, even before he was called upon to deliver God's message to humanity.

An Islamic approach requires a suitable regulatory framework. Islam, among other aspects of life, regulates commerce (Qur'ān 2:282). Without law, there would be anarchy. Prior to the current crises, there was excessive de-regulation, especially in the OTC (over-the-counter) market for debt-based securities, a legacy of the free market euphoria of the Thatcher and Reagan years. Islam recommends the 'middle path'- moderation and avoidance of extremes - whether in the direction of freedom or in the direction of authoritarianism.

Another Islamic response is to be optimistic. God has promised a generous reward to those whose intention is to do good. A verse in the Qur'ān (15:56) says that only those who go astray despair of the mercy of God. We must look at life in a cheerful way.

Expectations play a major role in people's decisions. People spend and invest more when they are optimistic. Pessimism has a demoralising effect. It reduces confidence and inhibits initiative. A verse in the Qur'ān (2:268) states that the evil one threatens all and sundry with poverty, but God invites all people to plenty. The current crisis is as much a crisis of confidence as it is a financial and economic crisis. To overcome the crisis, we need to become and remain confident. High morale is essential for success (falāhh).

It is necessary to reward real investment and discourage excessive speculation, which is akin to gambling. As there is a fine line between excessive speculation and legitimate business risk taking, it may not be possible to eliminate excessive speculation completely.

We can apply these and other Islamic responses to overcome the current crises, and prevent or at least mitigate, future crises. 
Economic theory and practice need to be based on ethical principles. The inherent instability in the financial and economic architecture stems in part from its disconnectedness from ethical values, such as when financial institutions engage in predatory lending practices. We need to recognise that the meaning of 'value' extends beyond its quantitative significance. Value is more that just the price of something. We need to establish and maintain a strong link between economics and ethics. This can be done by infusing economics with universal ethical values, such as the protection of life, religion, knowledge, family, and dignity. The Islamic concept of the 'common good' (maslahah) likewise needs to be incorporated into our understanding and practice of economics and finance. Too often, private interests conflict with (and even override) the interests of the people or the public interest.

Islam teaches ethics and a strong sense of moral purpose. The role of man on the earth is that of a 'deputy of God' (khalifah). Our responsibility is to manage the earth in accordance with the knowledge revealed to us by God Most High. We need to comprehend and apply that knowledge. We shall be judged on how well we managed - or mismanaged.

In order to optimise the greater common good, we need to design, implement and maintain effective enforcement mechanisms to limit excessive speculation and encourage real investment. In particular, we need to muster the collective will to implement, maintain and fine-tune the required regulatory framework. 